\title{
Stepping Through the Mirror: A Dystopian Vision of Regression and Stagnation in Tatyana Tolstaya's The Slynx.
}

\author{
DANICA JENKINS ${ }^{1}$ \\ University of Western Australia \\ thevinylhotel@westnet.com.au
}

\begin{abstract}
In her novel The Slynx', Tatyana Tolstaya creates a dystopian world of regression and stagnation to critically reflect upon the historical patterns of Russia. By interweaving the phantasmagorical with the real, she uses fiction as a vehicle to meditate upon the cycles of progress and degeneration that have plagued Russian history. In lieu of mere social criticism, Tolstaya's literary dystopia links the abstract world of fiction with the contemporary post-communist context of her writing, as a means to ruminate on the future direction of Russia at a time when the nation is at a crossroads. The Slyn'x thus illustrates not only the disorder of trying to rebuild society after communism, but exposes also how the turmoil of modern Russian society is intrinsically linked to deep-rooted traditions of autocracy and dehumanisation. Subsequently, she emphasises that these customs are not simply imposed upon people from a top-down system of oppression, but ascertains that they are propagated from within the Russian consciousness to form an eternal and ineradicable component of the Russian psyche.
\end{abstract}

The literary representation of a 'utopian idea' is a powerful speculative tool for social critique. ${ }^{2}$ The same may be said of the literary dystopia, insofar as it too relies on the power of the "literary imagination" 3 to proclaim its message in a vividly powerful way. In her novel The Slynx, 4 Tatyana Tolstaya creates a dystopian world to reflect upon various aspects of Russian history and culture. Yet her intent is not to highlight flaws in a particular utopian ideal, or even to create an explicit allegory of a specified political system or époque in Russian history. Rather, her creation of a world composed of both phantasmagorical and mundane elements, low cultural forms and highbrow Russian literary allusions becomes an alternate dimension from which one can critically examine the historical patterns of Russia. By interweaving the fantastic with the real, she uses fiction as a way to meditate upon the cyclical nature of progress and degeneration that has plagued Russian history, the enduring legacy of autocracy in Russian politics, and the seemingly perpetual stagnation of the nation. Additionally, she uses the text to consider the ways in which these motifs of Russian history have evidenced in the postcommunist context of her writing. Therefore, in lieu of mere social criticism, Tolstaya's literary dystopia links the abstract world of fiction with the concrete world of real life to

\footnotetext{
${ }^{1}$ Danica J enkins is a student of European Studies and French at the University of Western Australia. After years of pursuing journalism, politics and sociology under the guise of a Mass Communications degree, she found her true academic calling in Russian and Eastern European Literature. When not daydreaming about looking out of a grimy window on the trans-Siberian railway, she iss dancing flamenco, enjoying a good glass of wine, and like all writers, torturing herself relentlessly over her work with extreme masochism.

${ }^{2}$ K. Kumar, 'Utopia and Anti-Utopia in the Twentieth Century', in Utopia: The Search for the Ideal Society in the Western World in Roland Schaer, Gregory Claeys and Lyman Tower Sargent (eds.), New York, Oxford University Press in association with the New York Public Library, 2000, p.251.

${ }^{3}$ Op. cit., p.252.

4 T. Tolstaya, The Slynx, translated by J amey Gambrell, New York, New York Review of Books, 2003.
}

92 
allow her to ruminate on the direction of Russia at a time when the nation is at a crossroads. She reflects on Russian history by rendering a compelling illustration of the recurring themes of stasis and regression that have thus far governed Russian experience, while concurrently warning of the ruinous effect a perpetuation of these patterns would have on Russia's growth in the future.

Reading The Slynx as a dystopia, as opposed to a distinct allegory of a particular époque, allows one to critically reflect on more perennial aspects of Russian history and culture. One critic has declared the allegorical elements within the text as a "transparent" allusion to Soviet times, and indeed there are certain textual representations that are considerably emblematic of this period. ${ }^{5}$ To only read the text in this way, however, is restrictive as it neglects to consider its speculative and critical function. It is perhaps more appropriate to view the text as a canvas onto which Tolstaya projects figurative elements of Russian life in order to bring them under heightened scrutiny. Furthermore, as Karen Ryan-Hayes contends, for a dystopia to be effectively critical, recognisable links between the world described and the author's own social and historical situation must be drawn. ${ }^{6}$ It is thus pertinent to consider Tolstya's own context of post-Soviet Russia $^{7}$ as the impetus for her writing, and the text as a medium for critiquing the manner in which the conventions of post-communism impact upon the everyday lives of ordinary Russian people.

There are key aspects of the Russian post-communist experience that manifest themselves in The Slynx. As Helena Goscilo indicates, the diminishing living standards, the prominence of a "corrupt self serving oligarchy", the marginalisation of high culture, and the "cultural and political chaos that blighted Russia's nineties" are all elements that are present within in the text. ${ }^{8}$ It is important to note, however, that Tolstaya does not just include these aspects to illustrate life in a post-communist society. She satirises them in such a way to offer a subtle, yet vehement critique of their impact upon Russia and its people. For example, the government's corruption in the bureaucratic tax and payment system of Fyodor Kuzmichsk, as described by Benedikt, is both preposterous and comical. To collect wages, one must bend down to a tiny window, humbling to the "Paymaster Murza" who sits behind. ${ }^{9}$ (Receiving the wage itself is made a difficult task necessitating that one squeeze their hand through a tiny dark slot - to increase the odds of very few "chits" (currency) being grasped at all. ${ }^{10}$ Tax collection, conversely, is relatively efficient. The wide and spacious window of the "Tax Murza" facilitates a much easier transfer of money, with the tax amount of six and a half chits always rounded up

\footnotetext{
${ }^{5}$ For example, Alla Latynina suggests that the 'Blast' in the text is illustrative of the 1917 Bolshevik revolution, and such depictions as the warehouses where 'meager goodies are doled out on special days' and the fearful KGB-esque 'Saniturions' are simply symbolic representations of life under Communism. See Alla Latynina "There's Your Spiritual Renaissance for You": On Tatyana Tolstaya's The Slynx,' Russian Studies in Literature, 39, 2003, p.69 for further examples of this interpretation.

${ }^{6}$ K. L. Ryan-Hayes, Contemporary Russian Satire: A Genre Study, Cambridge, New York and Melbourne, Cambridge University Press, 1995, p. 202.

7 Tolstaya began writing the novel in 1986, the year of the Chernobyl nuclear disaster in Ukraine and continued through the early post-Communist years to finish in 2000.

${ }^{8}$ H. Goscilo, 'Dystopian Dreams,' The Women's Review of Books, 20, 2003, p.10.

${ }^{9}$ T. Tolstaya, The Slynx, op. cit., p.78.

${ }^{10}$ Ibid., p.77.
} 
to seven, because "you can't tear a chit in half". 11 Yet despite the obviousness of this legitimised government rort, Tolstaya's real criticism of it lies not in its mere representation, but rather in Benedikt's nonchalant acceptance of its absolute ludicrousness. As he casually acknowledges that this is "what government service means", 12 he represents the inclination of many people in post-communist Russia to tolerate without question the increasingly bureaucratic and unjust nature of Russian politics and culture. ${ }^{13}$ Olga Shevchenko observes in her study of Post-Soviet life that in the "midst of chaos and dissatisfaction that could have easily brought about a revolution from below", ordinary Russians continued to live and withstand "not only the economic hardships, but also the moral and psychological pressures of the time."14 Through Benedikt's failure to question the established order, which is satirised to highlight its irresponsibility and ineptitude, Tolstaya alludes to the detrimental effects of apathy in a society where escalating material difficulties have considerably increased hardship.

It is relevant at this point to consider the legacy of communism in post-communist society. As Shöpflin points out, "an overwhelming majority of those involved in state administration under post-communism acquired their bureaucratic habits under the culture of communism."15 Furthermore, despite the collapse of communism, postcommunist society was a far cry from a clean slate as a considerable amount of baggage from the past seemed "deeply and often subconsciously internalised" within the citizens themselves. ${ }^{16}$ Tolstaya represents this lingering communist echo in her text as a kind of intrinsic backwardness within the people that keeps them and their society locked in a world of stasis. She parodies this through Benedikt's blind reliance on, and repetition of various habits and superstitions of which he himself has no clear understanding. When Benedikt leaves for work one morning, he sets a wood beam across the front of the door to his izba and bolsters it with a stick. ${ }^{17} \mathrm{He}$ muses that even though there is nothing to steal in his izba, he does this out of habit because his Mother, an "Oldener" born before the Blast, told him how people of her time used to do the same. Benedikt continues, noting that "now the whole settlement lock[s] their doors with sticks". ${ }^{18}$ This illustration is not only emblematic of the reliance on residual habits from an outdated mode of existence, but the very idiocy of the obviously misinterpreted act itself - locking a door from the outside with a stick that anyone can remove - highlights the fact that the people are completely unaware of their own backwardness and ignorance. Tolstaya uses this example of misinterpretation, and blind faith in superstition and habit, to express her concern over the future of a society that clings to conventions of a bygone era. Although communism may have passed, its legacy is still a haunting feature of postcommunist society - both within the policies of the government and the hearts of people

\footnotetext{
${ }^{11}$ Ibid., p.79.

${ }^{12}$ Ibid., p.78.

13 See G. Schöpflin, The condition of Post-Communism', in Politics in Eastern Europe: 1945-1992, Oxford, Cambridge, Blackwell, 1993, for an overview of increasing bureaucratisation in Post-Soviet Russian society.

${ }^{14} \mathrm{O}$. Shevchenko, 'Bread and Circuses: Shifting Frames and Changing References in Ordinary Muscovites' political talk', Communist and Post-Communist Studies, Vol. 34, No.1, 2001, p.80.

${ }^{15}$ Schöpflin, op. cit., p.280.

${ }^{16}$ L. Holmes, Post-Communism: An Introduction, Cambridge, Oxford, Polity Press in association with Blackwell, 1997, p.16.

${ }^{17}$ T. Tolstaya, The Slynx, op. cit., pp.3-4.

${ }_{18}$ Ibid., p.4.
} 
themselves. ${ }^{19}$ Tolstaya thus fears that this reliance on communist instrumentality in post-communist society will stunt Russia's ability to progress in the future. ${ }^{20}$

Reading The Slynx as a dystopia allows the reader to view the ways in which Tolstaya critiques elements of her own post-communist society. Yet as it has also been suggested, rather than writing a "run-of-the mill" dystopia, she has created a parody of the genre. ${ }^{21}$ This is true to the extent that despite the associations with post-communism as previously discussed, the text also conveys timelessness by scrambling temporal layers. ${ }^{22}$ Tolstaya's parody of the dystopian style illustrates that the text does not just reflect on a specific era in Russia history, but seeks to emphasise the impact of more enduring aspects of Russian culture. Ryan-Hayes asserts that according to the prescriptive pattern of literary dystopias, the traditional dystopian plot features an attempt to subvert or destroy a sociopolitical situation that is despotic and oppressive. ${ }^{23}$ However in The Slynx, while the "cult of personality"24 ruler Fyodor Kuzmich could certainly be viewed as a despot - issuing decrees at whim and modelling himself as an "omniscient" leader 25 - his depiction by the author as a tiny dwarf ${ }^{26}$ that "squeals" and "scampers under a bookcase" when confronted with a potential coup ${ }^{27}$ lampoons this form of leadership otherwise closely aligned with figures such as Stalin or the old Tsars. ${ }^{28}$

Furthermore, rather than an attempt to "subvert" or "destroy" the autocratic rule, as Ryan-Hayes expects of a dystopian text, the successful overthrow of Kuzmich by Benedikt's equally as despotic father-in-law results in nothing more than a perpetuation of totalitarian rule. ${ }^{29}$ As a result, Tolstaya is able to criticise the repetitive nature of leadership that has plagued both communism and post-communism, ${ }^{30}$ and likewise, denounce the various forms of despotic leadership that have prevailed during numerous

\footnotetext{
${ }^{19}$ L. Holmes, Post-Communism: An Introduction, op. cit.

20 Indeed, this theme has been expressed before in Russian literature. In his novel Once Upon the River Love, Andreï Makine depicts an old Russified Chinese man who tells the story of a man in communist society who raises wolf-cubs - their paws bound by wire to impede them ever from walking - for the rewards paid on their pelts. After killing the cubs and receiving the bounty for their fleece, the man buys vodka to celebrate, drinks too much, and dies. The story becomes an image of the absurdity of life under communist instrumentality, whereby those who cling to communist conventions are doomed to go nowhere. Similarly, the wolves, representing Russia, are stunted from birth due to the nature of these practices and condemned to never grow strong as they should. See A. Makine, Once Upon the River Love, translated by Geoffrey Strachan, New York, Arcade Publishing, 1998, pp.140-141.

${ }^{21}$ N. Ivanova 'Grind the Peacack into Burkers: On Tatyana Tolstaya's The Slynx', Russian Studies in Literature, Vol. 39, No. 4, 2003, p.74.

22 Goscilo, op. cit., p.10.

${ }^{23}$ Ryan-Hayes, op. cit., p.228.

24 Goscilo, op. cit., p.10.

25 Ibid.

26 T. Tolstaya, The Slynx, op. cit., p.157.

27 Ibid., p.271.

${ }^{28}$ Richard Eder neatly sums up the satire behind this parody by describing Fyodor Kuzmich as "part Stalin, part Wizard of Oz". See R. Eder, 'Breathing Fire: Tatyana Tolstaya on Russia Past and Present', New York Times Book Review, January 26, 2003, p. 19.

29 Goscilo, op. cit., p.10.

30 Eric Hanley, Natasha Yershova, and Richard Anderson have coined the term "old wine in a new bottle" to describe the extent to which Russian elites have been reproduced across generations. They state with reference to the communist and post-communist context: "there is more continuity than discontinuity between the nomenklatura that dominated the Soviet Union in 1988 and the elites that rule over Russia toda"'. See E. Hanley, N. Yershova and R. Anderson, 'Russia - Old Wine in a New Bottle? The Circulation and Reproduction of Russian Elites: 1983-1993', Theory and Society, Vol. 24, No.5, 1995, p.641.
} 
stages of Russian history. The legacy of autocracy is one with roots that reach deep into the Russian past, 31 and consequently it is through this inversion of the traditional dystopian plot that Tolstaya condemns its continuation through communist and postcommunist society.

Many literary dystopias serve as a mirror; by reflecting on the negative effects of a utopian realisation - most likely a totalitarian society - the dystopia discredits the idealism of utopian thinking. ${ }^{32}$ Yet the world portrayed in The Slynx differs considerably from this paradigm. Its bizarre, otherworldly society seems completely removed from any kind of familiar reality, and the reader feels as if they have stepped through the mirror to the perverted other side, like Alice does in Lewis Carroll's Through the Looking-Glass. ${ }^{33}$ Tolstaya's creation of this tangent world, a distortion of the traditional dystopian form, allows her to explore in greater detail the notion of 'backwardness,' that I have previously noted. Alla Latynina asserts that underlying most classical dystopias is a "conflict that pits the principle of the individual against a faceless instrument that is seeking to repress all individuality". ${ }^{34}$ However, it becomes clear that Benedikt, the individual, does not find a faceless inhuman technological power structure operating. As Tolstaya demonstrates, the operations of power and processes of dehumanisation occur instead within the individual himself and also within the broader traditions of Russian culture. For example, Benedikt's obsession with books and reading does not pave the way to an enlightenment of any sort. Rather, it generates within him a tyrannical misanthropy that leads him to abuse and even kill others in order to acquire their books. The situation is laced with satire as Benedikt equates nursery rhymes with the same profundity as classical Russian poetry and literature ${ }^{35}$, or relates a book about knitting to the concept of freedom. ${ }^{36}$ It thus becomes evident that, although Benedikt can dimly understand the power of literature, he is unable to evaluate its worth because he comes from a society that is largely illiterate. ${ }^{37}$ Consequently, it is from this backwardness, represented by Benedikt's inability to engage critically with the books he consumes, that Tolstaya sees the growth of totalitarianism and dehumanisation. Her parody of the conventional dystopian form emphasises that the failure to question or engage with the political sphere - a particularly potent issue in post-Soviet Russian society ${ }^{38}$ - does not only perpetuate despotism imposed from leadership, but perhaps more dangerously, generates and nurtures it within Russian people themselves through their apathy.

\footnotetext{
31 The traditions of autocratic rule stem from Byzantine tradition and the doctrine of Caesaropapism (whereby the ruler is both Prince and Priest) of Emperor J ustinian in the $6^{\text {th }}$ century, and continued under the Tsars of the Russian state from Ivan the Great (fifteenth century) through to the Bolshevik revolution of 1917 which removed the last Tsar, Nicholas II from the throne. See T. Szamuely, Part 1: The Russian State Tradition', in The Russian Tradition, London, Martin Secker \& Walburg Limited, 1974, pp. 3-139 for a more detailed discussion on this point. There is also evidence to suggest that the autocratic tradition has continued to live on in Russian rulers throughout the last century. See R. G. Wesson, The Soviet State, Ideology and Patterns of Autocracy', Soviet Studies, Vol. 20, No.1, 1968, pp. 179-186, pp. 179-186 for further details on this point.

32 Ryan-Hayes, op. cit., pp.200-202.

33 L. Carroll, Alice's Adventures in Wonderland and Through the Looking-Glass, Camberwell, Penguin, 1998.

${ }^{34}$ Latynina, op. cit., p. 70.

35 T. Tolstaya, The Slynx, op. cit., p.201,

36 As Benedikt quotes from the book 'Plaiting and Knitting", he states: "when knitting the armhole, we cast on two extra loops for freedom of movement" (Ibid., 213).

${ }^{37}$ M. Deyrup, The Slynx: A novel by Tatyana Tolstaya; J amie Gambrell/ Pushkin's Children: Writings on Russia and Russians by Tatyana Tolstaya; J amie Gambrell', The Slavic and East European J ournal, Vol.48, No.1, 2004, p. 126.

38 See Shevchenko, op. cit., pp.80, 83, and 88 for examples of such apathy towards the government in post-Soviet society.
} 
This idea of regression and dehumanisation can be extended further. While Tolstaya certainly draws links to her own post-communist context, 39 the notion of an authoritarian attitude that is bred unconsciously from within the Russian people is something that she also sees as emblematic of Russian culture. In her book Pushkin's Children, 40 Tolstaya uses the terms "Great Terror" and "Little Terror" to explain her approach to Russian history. Where the "Great Terror" is the palpable manifestation of oppression and brutality imposed upon the Russian people by historical figures such as Stalin or Ivan the Terrible, ${ }^{41}$ the "Little Terror" is the essence of this materialisation, an enduring entity that has existed in Russian culture since time immemorial. ${ }^{42}$ She describes this "Little Terror" as something permanent. It lurks dormant beneath the surface for periods of time, arises to wreak havoc, and then descends once again to linger within the depths of Russia's collective subconscious. ${ }^{43}$ Through this understanding, Tolstaya contends that ordinary Russian people are therefore not apolitical, but rather, carry inside themselves the seeds of totalitarianism and destruction. The Neolithic-style backwardness ${ }^{44}$ of the people in The Slynx does not just represent the consequence of indifference towards a particular government or set of bureaucratic habits, but also illustrates the way in which this "Little Terror" condemns Russia to cycles of stagnation and regression. Tolstaya confesses the difficulties in representing this concept, as she states:

The backward notion of history, the submersion of culture under a thick layer of gilded, decorative 'Asiatic Savagery', government piracy, guile elevated to principle, unbridled caprice, extraordinary lack of will all combined with an impulsive cruelty... a blind, superstitious belief in the spoken, and especially written word... How can all this be described, how can one give a sense of the ocean from which the huge wave of Great Terror periodically rises? ${ }^{45}$

The reader, however, gets a sense that through The Slynx this is exactly what she is trying to describe. It is illustrated in the way that the tyrant Fyodor Kuzmich plagiarises the works of Russian literary greats and passes them off as his own. It is manifest in the cruel and abusive games that the people play on one another, and in the way they then laugh at the consequential injuries of others. ${ }^{46}$ It is exemplified through the inherent yet unrealised backwardness of the people, as "superstition, dread, oblivion and illiteracy form the base of society." ${ }^{77}$ Consequently, the depiction of all these aspects in The Slynx is Tolstaya's attempt to exemplify the social and psychological effects of the "Little Terror" within Russian consciousness. Furthermore, as the society in the text is illustrated as one that allegorises aspects of Tolstaya's own post-communist experience,

\footnotetext{
39 Goscilo, op. cit., pp.10.

40 T. Tolstaya, Pushkin's Children, translated by J amey Gambrell, New York and Boston, Houghton Mifflin Books, 2003.

41 Ibid., p.17.

42 Ibid., p.15.

43 Ibid., pp.15-17.

44 Goscilo, op. cit., p.10.

45 Tolstaya, op. cit., p.17.

46 Ibid., p.133.

${ }^{47}$ Goscilo, op. cit., p.10.
} 
yet simultaneously resembles a "larval level of existence", 48 it is demonstrated that she fears this "terror" as something eternal and ineradicable in Russian history.

Ultimately, Tolstaya uses the text to critique this cyclical and regressive nature of Russian history. From her understanding of the "terror" as previously discussed, one can garner that she sees the path of Russia not as one that progresses, but one that is cyclical, condemning and stagnating. As Goscilo notes, The Slynx itself reproduces the stasis it attempts to depict, as akin to the image of Russia it presents, the "novel operates by repetition, not development." 49 This is true insofar as the story does not seem to offer any real change or progress that amasses hope for the possibility of change. We see the overthrow of one despot lead to the reinstatement of another. We also see the emergence of atavistic characteristics such as tails, gills and cockscombs, as 'Consequences' of the Blast. There is also specific reference to a "lapti", a slipper made from bast, which was worn by Russians in the fifteenth and sixteenth centuries. ${ }^{50}$ As a result, there is a strong sense of regression and repetition that is characterised in the novel. Tolstaya uses the metaphor of a "meat grinder" to explore this fact. Left with only the instructions of the grinder as a reminder of its purpose, Nikita Ivanich, an Oldener, believes that although society has reverted to a stone-age level of subsistence, "the time of the meat grinder" will one day return as society rediscovers all its greatest inventions. ${ }^{51}$ On the other hand, Lev Lvovich, another Oldener, predicts only a repetition of past events. As he states: "the meat grinder hasn't changed, only the attachments have", 52 he reflects on what he sees as the cyclic nature of Russian society. That is, no matter what changes are implemented, he believes that society will continually advance to the same stage, only to once again destroy itself. Inevitably, it seems to be the second calculation that Tolstaya most agrees with, as the novel ends with a blast reminiscent of the one that spawned this primitive society. ${ }^{53}$ By ending the novel in such a way, through the repetition of an event instigated by a society plagued by repression, she meditates on what she sees as the crisis of Russia. Through the transmission of autocratic tradition, and the failure to question this trend, Russia has become locked into an endless loop of degradation and degeneration. Furthermore, given her illustration of the eternality of such cycles, this is something that Tolstaya imagines will lead only to further patterns of stagnation and collapse. 54

The dystopian quality of Tolstaya's text provides her with a powerful tool to meditate upon the patterns of Russian history and culture. The Slynx illustrates not only the

\footnotetext{
48 Ibid.

49 Ibid.

50 Tolstaya perhaps makes reference to lapti' as they themselves are a certain symbol of regression. She asserts in Pushkin's Children, p.17, that after Novgorod (a once independent republic of Russia) had been conquered by Moscow under Ivan the Terrible, many sophisticated elements of its culture were replaced by the more primitive tools used around Moscow. Such is the case with the Lapti, a simple slipper-like shoe made from plant fibers, which replaced the more sturdy leather boots that were used previously.

${ }^{51}$ Tolstaya, op. cit., p. 121,

52 Ibid., p.122.

53 Ibid., p.294.

54 Tolstaya herself has reflected on these very patterns in Russian history, by comparing them to the re-growth of fingerprints. She states: "when they invented fingerprinting, criminals tried to remove their prints by burning them or cutting them off. Yet they always grew back. If there is a pattern, it will come back - maybe in Russia more than anywhere else, because it has collapsed so many times."'See C. Bohlen, 'A Tolstoy Speaks, and Russia Listens', New York Times, J anuary 11, 2003, p.7.
} 
disorder of trying to rebuild society after communism, but exposes also how the turmoil of modern society is intrinsically linked to deep-rooted traditions of autocracy and dehumanisation that appear to be embedded within Russian history. By parodying conventional dystopian literature, Tolstaya is able to emphasise how these traditions are not simply imposed upon people from a top-down system of oppression. Rather, they are propagated from within the Russian consciousness, to form a cyclic pattern of regression and stagnation that governs the direction of Russian history. The failure of the Russian people to acknowledge these forces, she contends, only strengthens their hold over Russia's future. Meanwhile, Tolstaya does not attempt to propose any answers to these problems. This does not result in a devaluation of her analysis; in fact, it underscores the dangers of these obstacles all more powerfully. By illustrating the themes of regression, stagnation and authoritarianism in such a provocative way, she invokes a vivid picture of a dystopian world. This world, despite all its bizarreness, warns convincingly of how an apathetic attitude towards the institutionalisation of Russian cultural degeneration could severely stunt its ability to develop as a nation in the future. 